\title{
ЗМІНА ПОКАЗНИКІВ ГУМОРАЛЬНОГО ІМУНІТЕТУ ПРИ ВПЛИВІ РІЗНИХ ТИПІВ ЗАПАЛЬНОЇ РЕАКЦІЇ У ТВАРИН ІЗ ГАСТРОДУОДЕНІТОМ
}

На основі експериментального дослідження вивчено зміни показників циркулюючих імунних комплексів та різних класів імуноглобулінів у крові тварин із гастродуоденітом при різних типах запальної реакції. Як свідчать результати проведеного дослідження, в піддослідних тварин відзначають виражені порушення гуморального імунітету. В крові відмічають підвищення кількості імуноглобулінів та циркулюючих імунних комплексів. Найбільші зміни було виявлено у тварин з гіперергічним типом запальної реакції, найменші - 3 гіпоергічним, зміни у тварин з нормергічним типом займали проміжне місце.

КЛЮЧОВІ СЛОВА: типи запальної реакції, гастродуоденіт, циркулюючі імунні комплекси, імуноглобуліни класів A, M, G.

ВСТУП. Особливості морфологічних змін органів травної системи, вплив на їх слизову різних типів запальної реакції, складність та неоднозначність у трактуваннях основних патоморфологічних механізмів зумовили актуальність цієї проблеми.

Вчені відмітили, що характер перебігу запалення визначається співвідношенням чинників неспецифрічної і специфрічної реактивності. За наявності адекватної відповіді з боку обох систем запалення розвивається за нормергічним типом запальної реакції. При зниженні імунологічної і неспецифрічної резистентності відзначають гіпоергічний тип запальної реакції. Помірне зниження імунологічної резистентності характерне для гіперергічного типу запальної реакції $[1-3,2-4$, 7, 9].

На сьогодні доведено той фракт, що провідним фрактором розвитку і прогресування різноманітних захворювань $€$ не причина, яка викликала патологічний стан, а порушення, зумовлені зміненими, посиленими чи, навпаки, послабленими імунними процесами в організмі. 3'являється все більше підтверджень того, що будь-яке захворювання перебігає на сроні змінених окремих імунних білків та їх комплексів [6, 9-11].

Мета роботи - вивчити зміни показників гуморального імунітету у тварин із гастродуоденітом при різних типах запальної реакції.

(с) В. І. Бондарчук, 2016.
МЕТОДИ ДОСЛІДЖЕННЯ. Дослідження проведено на 42 білих нелінійних щурах-самцях, яких утримували у звичайних умовах та на стандартному раціоні віварію - відповідно до Науково-практичних рекомендацій з утримання лабораторних тварин та роботи з ними [8].

В усіх тварин моделювали гострий гастродуоденіт шляхом зондового введення у шлунок 0,25 мл $10 \% \mathrm{HO}-\mathrm{C}_{2} \mathrm{H}_{5}$, через 5 хв - 0,5 мл $1,25 \%$ розчину $\mathrm{HCl}$ [12]. Гіпоергічний тип запальної реакції моделювали, внутрішньом'язово вводячи алкілуючий цитостатик циклофооссран (ВАТ "Київмедпрепарат", Україна) (10 мг/кг маси тіла) за три дні до моделювання експериментального гастродуоденіту і щоденно протягом семи наступних днів. Гіперергічний тип запальної реакції моделювали, внутрішньом'язово вводячи пірогенал (НДІЕМ ім. М. Ф. Гамалеї РАMН, Росія) на фрізіологічному розчині (5 мінімальних пірогенних доз на одну тварину) за один день до моделювання експериментального гастродуоденіту і щоденно протягом семи днів. Нормергічний тип запальної реакції моделювали лише за допомогою експериментального гастродуоденіту без додаткового введення будь-яких речовин. Щурів виводили з експерименту на 7-му та 10-ту доби. Матеріалом для досліджень була сироватка крові тварин, в якій вивчали рівень $\lg$ A, M, G та циркулюючих імунних комплексів (ЦІК) [5]. 
Обробку результатів виконано у відділі системних статистичних досліджень Тернопільського державного медичного університету імені І. Я. Горбачевського в програмному пакеті Statsoft STATISTIKA. Різницю між порівнюваними величинами визначали за критерієм Манна-Уїтні.

РЕЗУЛЬТАТИ Й ОБГОВОРЕННЯ. ОДНИМ 3 індикаторів стану імунної системи організму $є$ рівень ЦІК у сироватці крові. Тривала циркуляція в організмі імунних комплексів при незначному зростанні їх рівня призводить до накопичення їх у тканинах, підвищеної агрегації і адгезії тромбоцитів, що спричиняє порушення мікроциркуляції та облітерацію судин гемомікроциркуляторного русла, пошкодження і некроз тканин. За умов зміненої реактивності у крові щурів із гастродуоденітом було встановлено зміни, які зовні проявлялися зменшенням маси тіла та кровоточивістю. Поряд із тим, аналіз отриманих результатів свідчить про наявність розладів у фуннціонуванні імунної системи організму тварин.

У тварин із гіперергічним типом запальної реакції вміст ЦІК, порівняно з контролем, був вищим на 7-му добу дослідження на $84 \%(\mathrm{p}<0,05)$, на 10-ту - на 89,4 \% (p<0,05). Порівнюючи показники цієї ж групи щурів із нормергічним типом запальної реакції, виявили, що вміст ЦІК був більшим на 7-му добу дослідження на 7,3 \% $(\mathrm{p}<0,05)$, на 10-ту - на 6,3\% (p<0,05). Порівняно 3 показниками тварин із гіпоергічним типом за- пальної реакції вміст ЦІК також був вищим на 7-му добу дослідження на 17,6 \% (p<0,05), на 10-ту - на 19,1 \% (p<0,05).

Вміст ЦІК у сироватці крові залежить від ряду чинників, зокрема активності В-лімсооцитів продукувати імуноглобуліни.

Встановлено, що рівень $\lg$ A, M, G був вищим відносно контролю в усіх досліджуваних групах тварин.

У тварин із гіперергічним типом запальної реакції рівень Ig А був вищим на 7-му добу дослідження на $76 \%(p<0,05)$, на 10-ту - на 78,2\% $(\mathrm{p}<0,05) ;$ рівень Ig М був вищим на 7-му добу дослідження на 24,4 \% ( $<<0,05)$, на 10-ту - на $23,4 \%(p<0,05) ;$ рівень Ig G був вищим на 7-му добу дослідження на 69 \% (p<0,05), на 10-ту - на 70,1 \% (p<0,05). Порівнюючи показники цієї групи щурів 3 показниками тварин із нормергічним типом запальної реакції, виявили, що рівень $\lg \mathrm{A}$ був більшим на 7-му добу дослідження на 9,1 \% $(p<0,05)$, на 10-ту - на 8,9 \% ( $<<0,05) ;$ відмінності рівня Ig М у цієї групи щурів з показниками тварин із нормергічним типом запальної реакції на 7-му та 10-ту доби дослідження були недостовірними. При порівнюванні тієї ж групи щурів із тваринами з гіпоергічним типом запальної реакції слід відмітити, що рівень $\lg$ А був вищим на 7-му добу дослідження на 39,4 \% (p<0,05), на 10 -ту - на 38,8 \% (p<0,05); відмінності рівня Ig M, $\mathrm{G}$ у цієї групи щурів з показниками тварин із гіпоергічним типом запальної реакції на 7-му та 10-ту доби дослідження були недостовірними (табл. 1).

Таблиця 1 - Показники гуморального імунітету у тварин із гіперергічним типом запальної реакції $(\mathrm{M} \pm \mathrm{m})$

\begin{tabular}{|l|c|c|c|}
\hline \multirow{2}{*}{ Показник } & \multirow{2}{*}{ Контроль } & \multicolumn{2}{|c|}{ Термін дослідження } \\
\cline { 3 - 4 } & \multirow{2}{*}{ ЦІК, ум. од. } & 7 -ма доба & 10-та доба \\
& & $119,000 \pm 0,516$ & $122,500 \pm 0,847$ \\
& & $p_{1}<0,05$ & $p_{1}<0,05$ \\
& $0,556 \pm 0,011$ & $p_{2}<0,05$ & $p_{2}<0,05$ \\
\hline $\lg \mathrm{A}$, г/л & $0,979 \pm 0,003$ & $0,991 \pm 0,004$ \\
& & $p_{1}<0,05$ & $p_{1}<0,05$ \\
& & $p_{2}<0,05$ & $p_{2}<0,05$ \\
\hline $\lg$ M, г/л & $0,754 \pm 0,004$ & $0,938 \pm 0,014$ & $0,931 \pm 0,015$ \\
& & $p_{1}<0,05$ & $p_{1}<0,05$ \\
& & $p_{3}>0,05$ & $p_{3}>0,05$ \\
& & $p_{4}>0,05$ & $p_{4}>0,05$ \\
\hline $\lg$ G, г/л & $1,423 \pm 0,005$ & $1,433 \pm 0,002$ \\
& $0,842 \pm 0,003$ & $p_{1}<0,05$ & $p_{1}<0,05$ \\
& & $p_{2}<0,05$ & $p_{2}<0,05$ \\
& & $p_{3}>0,05$ & $p_{3}>0,05$ \\
\hline
\end{tabular}

Примітки:

1. $\mathrm{p}_{1}$ - наведені результати достовірно відрізняються від показників контрольної групи тварин.

2. $p_{2}$ - наведені результати достовірно відрізняються між дослідними групами тварин.

3. $p_{3}$ - наведені результати не достовірні з показниками тварин із гіпоергічним типом запальної реакції.

4. $\mathrm{p}_{4}$ - наведені результати не достовірні з показниками тварин із нормергічним типом запальної реакції. 
У тварин із нормергічним типом запальної реакції вміст ЦІК був вищим, відносно контролю, на 7-му добу дослідження на 71,3 \% (p<0,05), на 10 -ту - на 78 \% (p<0,05). Порівнюючи показники цієї ж групи тварин з показниками щурів із гіпоергічним типом запальної реакції, встановили, що вміст ЦІК був більшим на 7-му добу дослідження на 9,5 \% (p<0,05), на 10-ту - на 11,9\% $(\mathrm{p}<0,05)$. Порівняно $з$ тваринами 3 гіперергічним типом запальної реакції вміст ЦІК був нижчим на 7-му добу дослідження на 6,8 \% (p<0,05), на 10-ту - на 5,9 \% (р<0,05).

У тварин із нормергічним типом запальної реакції, порівняно з контролем, рівень Ig А був вищим на 7-му добу дослідження на 61,3 \% (p<0,05), на 10-ту - на 63,6 \% ( $<<0,05) ;$ рівень Ig M був більшим на 7-му добу дослідження на 20,5 \% $(p<0,05)$, на 10-ту - на $21 \%(p<0,05)$; рівень Ig G також був вищим на 7-му добу дослідження на $67,9 \%$ (p<0,05), на 10-ту - на 66,6 \% (p<0,05). Порівнюючи показники цієї ж групи щурів з показниками тварин із гіпоергічним типом запальної реакції, встановили, що рівень Ig А був вищим на 7-му дослідження на 27,7 \% (p<0,05), на 10-ту на 27,4 \% (p<0,05); відмінності рівня Ig M, G у цієї групи щурів з показниками тварин із гіпоергічним типом запальної реакції на 7-му та 10-ту доби дослідження були недостовірними. Порівняно 3 групою тварин із гіперергічним типом запальної реакції варто відмітити зниження рівня Ig A на 7-му добу дослідження на 8,3 \% ( $p<0,05)$, на 10 -ту - на 8,1 \% (p<0,05); відмінності рівня Ig $\mathrm{M}$, $\mathrm{G}$ у щурів із нормергічним типом запальної реакції з показниками тварин із гіперергічним типом запальної реакції на 7-му та 10-ту доби дослідження були недостовірними (табл. 2).

Таблиця 2 - Показники гуморального імунітету у тварин із нормергічним типом

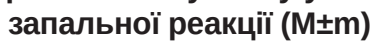

\begin{tabular}{|l|c|c|c|}
\hline \multirow{2}{*}{ Показник } & \multirow{2}{*}{ Контроль } & \multicolumn{2}{|c|}{ Термін дослідження } \\
\cline { 2 - 4 } & & 7 -ма доба & 10 -та доба \\
\hline ЦІК, ум. од. & $64,667 \pm 1,116$ & $110,883 \pm 1,600$ & $115,167 \pm 1,195$ \\
& & $\mathrm{p}_{1}<0,05$ & $\mathrm{p}_{1}<0,05$ \\
& & $\mathrm{p}_{2}<0,05$ & $\mathrm{p}_{2}<0,05$ \\
\hline Ig A, г/л & $0,556 \pm 0,011$ & $0,897 \pm 0,015$ & $0,910 \pm 0,002$ \\
& & $\mathrm{p}_{1}<0,05$ & $\mathrm{p}_{1}<0,05$ \\
& & $\mathrm{p}_{2}<0,05$ & $\mathrm{p}_{2}<0,05$ \\
\hline $\lg \mathrm{M}$, г/л & $0,909 \pm 0,003$ & $0,913 \pm 0,011$ \\
& $0,754 \pm 0,004$ & $\mathrm{p}_{1}<0,05$ & $\mathrm{p}_{1}<0,05$ \\
& & $\mathrm{p}_{3}>0,05$ & $\mathrm{p}_{3}>0,05$ \\
& & $\mathrm{p}_{4}>0,05$ & $\mathrm{p}_{4}>0,05$ \\
\hline Ig G, г/л & $1,414 \pm 0,003$ & $1,403 \pm 0,004$ \\
& & $\mathrm{p}_{1}<0,05$ & $\mathrm{p}_{1}<0,05$ \\
& $0,842 \pm 0,003$ & $\mathrm{p}_{4}>0,05$ & $\mathrm{p}_{3}>0,05$ \\
\hline
\end{tabular}

Примітки:

1. $p_{1}$ - наведені результати достовірно відрізняються від показників контрольної групи тварин.

2. $p_{2}$ - наведені результати достовірно відрізняються між дослідними групами тварин.

3. $\mathrm{p}_{3}$ - наведені результати не достовірні з показниками тварин із гіпоергічним типом запальної реакції.

4. $\mathrm{p}_{4}$ - наведені результати не достовірні з показниками тварин із гіперергічним типом запальної реакції.

У тварин із гіпоергічним типом запальної реакції було відмічено збільшення вмісту ЦІК, порівняно з контролем, на 7-му добу дослідження на $56,4 \%(p<0,05)$, на $10-$ ту - на $59 \%(p<0,05)$. При порівнюванні показників цієї ж групи щурів з показниками тварин із нормергічним типом запальної реакції виявили, що вміст ЦІК був нижчим на 7-му добу дослідження на 8,7 \% $(p<0,05)$, на 10-ту - на 10,7 \% (p<0,05). Порівняно з показниками тварин із гіперергічним типом запальної реакції вміст ЦІК був меншим на 7-му добу дослідження на 14,9 \% ( $<<0,05)$, на 10-ту - на $16 \%(p<0,05)$.

У тварин із гіпоергічним типом запальної реакції, порівняно з контролем, рівень Ig А був вищим на 7-му добу дослідження на 26,2 \% $(p<0,05)$, на 10-ту - на 28,4 \% $(p<0,05)$; рівень
Ig М був більшим на 7-му добу дослідження на $19,2 \%$ ( $p<0,05)$, на 10-ту - на 20,4 \% ( $<<0,05)$; рівень Ig G також був вищим на 7-му добу дослідження на 65,9 \% $(\mathrm{p}<0,05)$, на 10-ту - на $66,5 \%(p<0,05)$.

У щурів із гіпоергічним типом запальної реакції, порівняно з показниками тварин із нормергічним типом, рівень Ig А був нижчим на 7-му добу дослідження на 21,7 \% ( $<<0,05)$, на 10-ту - на 21,5 \% $(p<0,05)$; відмінності рівня $\lg$ M, G у цієї групи щурів з показниками тварин із нормергічним типом запальної реакції на 7-му та 10-ту доби дослідження були недостовірними. Порівняно з показниками тварин із гіперергічним типом запальної реакції рівень Ig А був нижчим на 7-му добу дослідження на 28,2 \% ( $p<0,05)$, на 10-ту - на 27,9 \% $(p<0,05)$; відмінності рівня 
$\lg$ M, G у цієї групи щурів з показниками тварин та 10-ту доби дослідження були недостовірними із гіперергічним типом запальної реакції на 7-му (табл. 3).

Таблиця 3 - Показники гуморального імунітету у тварин із гіпоергічним типом

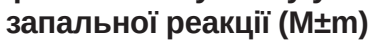

\begin{tabular}{|l|c|c|c|}
\hline \multirow{2}{*}{ Показник } & \multirow{2}{*}{ Контроль } & \multicolumn{2}{|c|}{ Термін дослідження } \\
\cline { 2 - 3 } & & $7-$ ма доба & 10-та доба \\
\hline ЦІК, ум. од. & $64,667 \pm 1,116$ & $101,167 \pm 0,946$ & $102,833 \pm 0,654$ \\
& & $p_{1}<0,05$ & $p_{1}<0,05$ \\
& & $p_{2}<0,05$ & $p_{2}<0,05$ \\
\hline $\lg$ A, г/л & $0,556 \pm 0,011$ & $0,702 \pm 0,003$ & $0,714 \pm 0,002$ \\
& & $p_{1}<0,05$ & $p_{1}<0,05$ \\
& & $p_{2}<0,05$ & $p_{2}<0,05$ \\
\hline $\lg$ M, г/л & $0,899 \pm 0,005$ & $0,908 \pm 0,002$ \\
& $0,754 \pm 0,004$ & $p_{1}<0,05$ & $p_{1}<0,05$ \\
& & $p_{3}>0,05$ & $p_{3}>0,05$ \\
& & $p_{4}>0,05$ & $p_{4}>0,05$ \\
\hline $\lg$ G, г/л & $1,397 \pm 0,003$ & $1,402 \pm 0,002$ \\
& $0,842 \pm 0,003$ & $p_{1}<0,05$ & $p_{1}<0,05$ \\
& & $p_{2}<0,05$ & $p_{2}<0,05$ \\
& & $p_{4}>0,05$ & $p_{3}>0,05$ \\
& & & $p_{4}>0,05$ \\
\hline
\end{tabular}

Примітки:

1. $p_{1}$ - наведені результати достовірно відрізняються від показників контрольної групи тварин.

2. $\mathrm{p}_{2}$ - наведені результати достовірно відрізняються між дослідними групами тварин.

3. $\mathrm{p}_{3}$ - наведені результати не достовірні з показниками тварин із нормергічним типом запальної реакції.

4. $\mathrm{p}_{4}$ - наведені результати не достовірні з показниками тварин із гіперергічним типом запальної реакції.

Проведене дослідження виявило, що рівень імуноглобулінів (Ig A, M, G) у сироватці крові всіх груп тварин підвищувався.

Показники рівня $\lg$ А найбільшими були у групі тварин із гіперергічним типом запальної реакції $((0,991 \pm 0,004)$ г/л), найменшими - в щурів із гіпоергічним типом $((0,714 \pm 0,002)$ г/л), тварини $з$ нормергічним типом займали проміжне місце між гіпер- та гіпоергічним типами $((0,910 \pm 0,002)$ г/л).

У групі тварин із гіперергічним типом запальної реакції показники були найвищими $((0,938 \pm 0,014)$ г/л). Група щурів із нормергічним типом займала проміжне місце $((0,913 \pm$ $0,003)$ г/л). У тварин із гіпоергічним типом рівень Ig М був найнижчим $((0,899 \pm 0,005)$ г/л).

У групі тварин із гіперергічним типом запальної реакції рівень $\lg \mathrm{G}$ мав найвищі показники $((1,433 \pm 0,002)$ г/л). Рівень $\lg G$ у групі щурів із нормергічним типом займав проміжне місце $((1,414 \pm 0,003))$ г/л. У групі тварин із гіпоергічним типом рівень $\lg \mathrm{G}$ був нижчим, ніж у групі щурів із норм- та гіперергічним типами $((1,402 \pm 0,002)$ г/л).

Отже, як свідчать результати дослідження, вміст ЦІК у сироватці крові тварин з різними типами запальної реакції зростав на 10-ту добу експерименту. В щурів із гіперергічним типом запальної реакції вміст ЦІК був найбільшим $((122,500 \pm 0,847)$ ум. од.), найменший вміст ЦІК відмічено у крові тварин із гіпоергічним типом

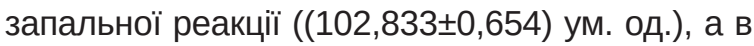
щурів із нормергічним типом запальної реакції вказаний показник займав проміжне місце

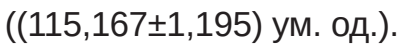

Отримані результати свідчать про те, що тип запальної реакції істотно впливає на особливості змін гуморального імунітету в досліджуваних груп тварин із гастродуоденітом. Найбільш значні зміни було виявлено в щурів із гастродуоденітом при гіперергічному типі запальної реакції, найменші -при гіпоергічному, у тварин із гастродуоденітом при нормергічному типі запальної реакції зміни займали проміжне місце.

ВИСНОВКИ. 1. Ступінь порушень гуморального імунітету в досліджуваних груп тварин залежить від типу запальної реакції.

2. Найбільш значні зміни було виявлено в щурів із гіперергічним типом запальної реакції, найменші - 3 гіпоергічним, у тварин із нормергічним типом зміни займали проміжне місце.

3. Зміни гуморального імунітету супроводжувалися зростанням показників циркулюючих імунних комплексів та $\lg \mathrm{A}, \mathrm{M} \mathrm{i} \mathrm{G}$ відносно контролю впродовж 10 діб.

4. Отримані результати є експериментальним підґрунтям для проведення подальших досліджень щодо морфологічних змін слизової оболонки порожнини рота при впливі різних типів запальної реакції у тварин із гастродуоденітом. 


\section{СПИСОК ЛІТЕРАТУРИ}

1. Авдєєв О. В. Порівняльна оцінка загальнофрізіологічних змін у тварин із запаленням у пародонті за зміненої реактивності / О. В. Авдєєв // Актуальні проблеми сучасної медицини: вісник Української медичної стоматологічної академії. -2011. - 11, вип. 2 (34). - C. 4-6.

2. Борисенко М. І. Вивчення в експерименті та клініці ефективноті імуномодуляції в комплексному лікуванні хронічного запального процесу в слизовій оболонці гастродуоденальної зони / М. І. Борисенко, Ю. Б. Чайковський // Профрілактична медицина. 2009. - № 1. - С. 40-45.

3. Борисенко М. І. Стан місцевого імунітету шлунка та дванадцятипалої кишки при хронічному гастродуоденіті у дітей / М. І. Борисенко // Перинатологія та педіатрія. - 2007. - № 1. - С. 28-33.

4. Борисенко М. І. Імуномодуляція місцевого імунітету верхніх відділів травного каналу при хронічному запальному процесі його слизової оболонки // Суч. гастроентерол. - 2006. - № 1 (27). - С. 41-45.

5. Гриневич Ю. А. Определение иммунных комплексов в крови онкологических больных / Ю. А. Гриневич, А. М. Алферов // Лаб. дело. - 1981. - № 8. С. 493-495.

6. Кайдашев И. П. Очерки иммунобиологии слизистой оболочки полости рта / И. П. Кайдашев. - Полтава, 2008. - 304 с.
7. Климович В. Б. Иммуноглобулин A (IgA) и его рецепторы / В. Б. Климович, М. П. Самойлович // Мед. иммунология. - 2006. - 8, № 4. - С. 483-500.

8. Науково-практичні рекомендації з утримання лабораторних тварин та роботи з ними / Ю. М. Кожем'якін, О. С. Хромов, М. А. Філоненко, Г. А. Сайсретдінова. - К . : Авіцена, 2002. - 156 с.

9. Запалення - типовий патологічний процес / М. С. Регеда, Т. С. Бойчук, Ю. І. Бондаренко, М. М. Регеда. - 2-ге вид., допов. та переробл. - Львів, 2013. $148 \mathrm{c}$.

10. Чернушенко Е. Ф. Иммунологические исследования в клинике / Е. Ф. Чернушенко, Л. С. Колосова. - К. : Здоров'я, 1987. - 159 с.

11. Шумский А. В. Иммунопатогенетический подход в лечении воспалительных заболеваний полости рта / А. В. Шумский // Пародонтология. -2005. - № 4. C. $26-28$.

12. Пат. 98021 Україна, МПК (51) G09B 23/78 G01N 23/48 G01N 33/84 G01N 33/98 (2006.01). Спосіб моделювання запальних процесів слизової оболонки порожнини рота / Мисула Н. І., Авдєєв О. В. ; Тернопільський державний медичний університет імені І. Я. Горбачевського. - № u201010071 ; заявл. и 2014 12673 ; опубл. 10.04.15, Бюл. № 7.

В. И. Бондарчук

ТЕРНОПОЛЬСКИЙ ГОСУДАРСТВЕННЫЙ МЕДИЦИНСКИЙ УНИВЕРСИТЕТ ИМЕНИ И. Я. ГОРБАЧЕВСКОГО

\section{ИЗМЕНЕНИЕ ПОКАЗАТЕЛЕЙ ГУМОРАЛЬНОГО ИММУНИТЕТА ПРИ ВЛИЯНИИ РАЗЛИЧНЫХ ТИПОВ ВОСПАЛИТЕЛЬНОЙ РЕАКЦИИ У ЖИВОТНЫХ С ГАСТРОДУОДЕНИТОМ}

Резюме

На основе экспериментального исследования изучены изменения показателей циркулирующих иммунных комплексов и различных классов иммуноглобулинов в крови животных с гастродуоденитом при различных типах воспалительной реакции. Как свидетельствуют результаты проведенного исследования, в подопытных животных отмечают выраженные нарушения гуморального иммунитета. В крови отмечают повышение количества иммуноглобулинов и циркулирующих иммунных комплексов. Наибольшие изменения были обнаружены у животных с гиперергическим типом воспалительной реакции, наименьшие - с гипоергическим, изменения у животных с нормергическим типом занимали промежуточное место.

КЛЮЧЕВЫЕ СЛОВА: типЫ воспалительной реакции, гастродуоденит, циркулирующие иммунные комплексы, иммуноглобулины классов А, M, G. 


\section{CHANGE OF HUMORAL IMMUNITY IN VARIOUS TYPES OF INFLAMMATORY REACTIONS IN ANIMALS WITH GASTRODUODENITIS}

\section{Summary}

Based on experimental research there were studied the changes of indicators of circulating immune complexes and different classes of immunoglobulin's in the blood of animals with gastroduodenitis in various types of inflammatory reactions. The study found that experimental animals are marked expressed violations of humoral immunity. In blood there was marked increase in the number of immunoglobulin's and circulating immune complexes. The biggest changes were found in animals with hyperergic type of inflammatory reaction, the least - with hypoergic type, changes in animals with normergic type occupy an intermediate position.

KEY WORDS: types of inflammatory reactions, gastroduodenitis, circulating immune complexes, immunoglobulin A, M, G.

Отримано 15.07.16

Адреса для листування: В. І. Бондарчук, Тернопільський державний медичний університет імені І. Я. Горбачевського, м. Волі, 1, Тернопіль, 46001, Україна, e-mail: bondarchykvi@tdmu.edu.ea. 